\title{
BIOTYPING AND GENOTYPIC DIVERSITY AMONG ORAL CANDIDA ALBICANS STRAINS FROM CARIES-FREE AND CARIES-ACTIVE HEALTHY CHILDREN
}

\author{
Rita de Cássia Mardegan; Marlise Inêz Klein; Magda Baglione Golvea; Janaina Aparecida Oliveira Rodrigues; \\ Reginaldo Bruno Gonçalves; José Francisco Höfling*
}

Laboratório de Microbiologia e Imunologia, Departamento de Diagnóstico Oral, Faculdade de Odontologia, Universidade Estadual de Campinas, Piracicaba, SP, Brasil

Submitted: June 14, 2004; Returned to authors for corrections: September 27, 2004; Approved: February 22, 2006

\begin{abstract}
Candida albicans oral strains collected from caries-free and caries-active healthy children ranging from 24 to 36 months old, were studied. The aim of the study was to determine proteinase and phospholipase activities produced by Candida albicans in the two groups and to determine the phenotypic diversity of these enzymes based on genetic polymorphism using the AP-PCR method. Strains identified by morphological and fermentation tests as C. albicans were grown in proteinase and phospholipase agar media at $37^{\circ} \mathrm{C}$ for 7 and 4 days, respectively. After the incubation period, the enzyme activity of the proteinase and phospholipase positive strains was measured. All strains were subjected to AP-PCR, using the arbitrary primer AP-3. The enzymatic analysis showed no differences between the two groups. The AP-PCR method was effective in demonstrating intra-individual genetic polymorphism in C. albicans, showing a greater clonal diversity in caries-active versus caries-free children. Dendograms of similarity showed only intra-individual clonal lineage. The results suggest that the enzymatic profile does not depend on the genotypic characteristics of the strains.
\end{abstract}

Key words: Candida albicans, genotyping, proteinase, phospholipase, virulence

\section{INTRODUCTION}

Fungi of the genus Candida spp inhabit different epithelial surfaces of the body, including the oral mucosa, as part of the resident microbiota. The oral mucosa is considered to be a unique environment offering a variety of ecological niches for microbial colonization (18).

One of the factors that can flow and systemic disorders (38) and multiple caries $(12,24,28)$ Yeasts are more prevalent play an important role in the colonization of these microorganisms is the age of the host (14) and various conditions such as quality of diet (33), deficient oral hygiene (31), changes in saliva flow and systemic disorders (38) and multiple caries $(12,24,28)$. Yeasts are more prevalent in the saliva and dental biofilm of caries-active individuals than of caries-free individuals $(5,28)$

The species Candida albicans, considered as one of the most pathogenic, is the most frequently isolated yeast from the buccal cavity (38). It shows various mechanisms that are suggestive of virulence such as: capacity to take on various forms, called adaptive variations; ability to form hyphae; capacity to adhere to mucosal surfaces; produces hydrolytic enzymes; proteinases which hydrolyze peptides (10) and phospholipases which hydrolyze phospholipids (11).

In addition to phenotypic methods for the determination of pathogenic potential, the use of molecular methods have

*Corresponding author. Mailing address: Laboratório de Microbiologia e Imunologia, Departamento de Diagnóstico Oral, Faculdade de Odontologia, UNICAMP. Av. Limeira, 901. 13414-900, Piracicaba, SP, Brasil. Tel.: (+5519) 3412-5321 - 5322/5323. Fax: (+5519) 3412 5321. E-mail: hofling@ fop.unicamp.br 
currently become important, which can provide valuable information by their capacity to distinguish distinct isolates of the same species. With the use of arbitrarily primed polymerase chain reaction (AP-PCR), one or more genetic profiles of Candida albicans can be found in the same individual (20).

The aim of the present study was to compare the genotypic and phenotypic (enzymatic) profile of strains of Candida albicans, isolated from the oral cavity of caries-active and cariesfree children, in addition to examining the genotypic diversity of the yeast within and among individuals of these groups.

\section{MATERIALS AND METHODS}

The study included 158 strains of Candida albicans isolated from the oral cavity of healthy children aged 24 to 36 months, of both sexes, who were undergoing dental treatment (caries-active and caries-free). The clinical specimens were collected with a swab, from saliva (S), tongue dorsum (T), palate mucosa (PAL), jugal mucosa (B) and dental biofilm (PL). They were immersed in $1 \mathrm{~mL}$ sterile saline and the tubes then agitated for $30 \mathrm{sec}$. Aliquots of $100 \mu \mathrm{L}$ from the clinical specimens were immediately diluted 10-fold and 100-fold in sterile saline, and aliquots of 100 $\mu \mathrm{L}$ from each dilution, in duplicate, were inoculed in plates containing Sabouraud dextrose agar - DAS (Merck/Germany) added of $0.1 \mathrm{mg} / \mathrm{mL}$ chloramphenicol (Quemicetina Succinato/ Carlos Erba), and incubated aerobically at $37^{\circ} \mathrm{C}$ for 2 to 4 days. After incubation, representative colonies, were transferred to CHROMagar Candida medium (Probac do Brasil), for presumptive identification of Candida spp. Additional tests, such the germ tube test, the presence of hyphae, pseudo-hyphae, yeast-form cells and chlamydospores, plus the fermentation and assimilation of carbohydrates (34), were part of the species characterization. For presumptive identification of Candida dubliniensis, the strains identified as Candida albicans were tested for thermotolerance at $45^{\circ} \mathrm{C}(40)$

\section{Proteinase and phospholipase assays}

Strains identified as Candida albicans were transferred to flasks containing $5 \mathrm{~mL}$ yeast peptone dextrose medium (YPD) - $10 \mathrm{~g}$ yeast extract, $10 \mathrm{~g}$ peptone, $10 \mathrm{~g}$ glucose and distilled water up to $1000 \mathrm{~mL}$ - and incubated at $37^{\circ} \mathrm{C}$ for $18 \mathrm{~h}$. Following incubation, $1.5 \mathrm{~mL}$ of the yeast culture were transferred to an eppendorf tube and centrifuged at $3000 \mathrm{rpm}$, for $5 \mathrm{~min}$. The pellets obtained were washed twice by resuspension in saline and centrifugation under the same conditions to remove residual culture medium. After standardizing the suspensions (at index of 5 on the MacFarland scale), volumes of $1 \mu \mathrm{L}$ were plated in duplicate, at equidistant points, in phospholipase agar medium - peptone, $10 \mathrm{~g}$; glucose, $30 \mathrm{~g}$; $\mathrm{NaCl}, 57.3 \mathrm{~g} ; \mathrm{CaCl}_{2}$, $0.55 \mathrm{~g}$; distilled water added to $1000 \mathrm{~mL}$ and $50 \%$ egg yolk enrichment $100 \mathrm{~mL}$ (Laborclin) - and proteinase agar - BSA fraction $\mathrm{V}, 2 \mathrm{~g}$; yeast nitrogen base - w/o amino acids; ammonium sulfate, 1.45g; glucose, 20g; agar, 20g; distilled water added to $1000 \mathrm{~mL}$ - respectively. The plates containing inoculates of different strains for the detection of proteinases were incubated at $37^{\circ} \mathrm{C}$ for 7 days (29) and those used to detect phospholipase, cultured for 4 days, at the same temperature (27). The presence of phospholipase was determined by the formation of an opaque zone around the yeast colonies; enzyme activity (PZ) was measured by dividing the diameter of the colony by the diameter of the colony plus precipitation zone (27). The presence of proteinase was determined by the formation of a transparent halo around the yeast colonies and enzyme activity (PZ) was measured in the same manner as described for phospholipase (Fig. 1).
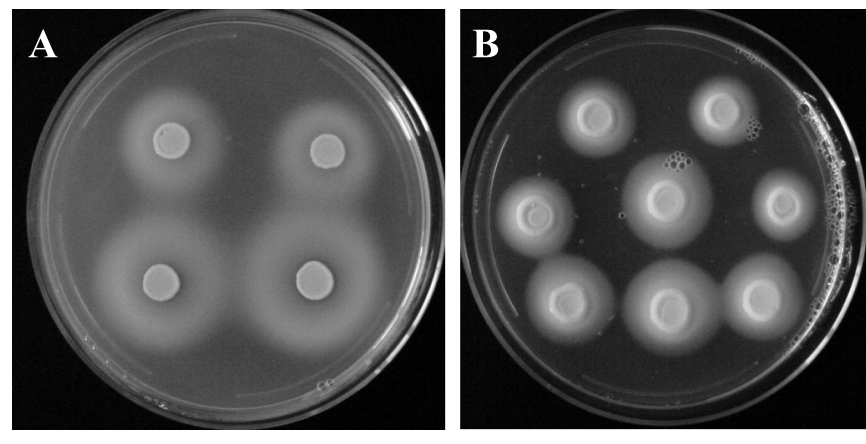

Figure 1. Culture of Candida albicans in specific media for the induction of proteinase (A) e phospholipase (B). Growth of 4 strains of Candida albicans in proteinase agar (A) and 8 strains of $C$. albicans in phospholipase agar (B). After incubation period, zones of degradation (A) and/or precipitation (B) could be seen around the yeast colonies.

\section{DNA extraction}

Strains of Candida albicans were transferred to flasks with $5 \mathrm{~mL}$ yeast peptone dextrose (YPD) and incubated at $37^{\circ} \mathrm{C}$ for $18 \mathrm{~h}$. Afterward, they were submitted to DNA extraction (4). The concentration and purity of DNA were confirmed by spectrophotometric analysis at 260 and $280 \mathrm{~nm}$ (Genesys 10UVRochester/NY-USA).

\section{AP-PCR}

The AP-PCR reaction utilizing the arbitrary primer AP-3 (5'TCACGATGCA3 ${ }^{\circ}$ ), described by 41 , was carried out according to 30 , whereby about 300 ng DNA were added to a reaction mixture containing buffer solution ( $1 \mathrm{x}$ Taq polymerase reaction buffer), $3.5 \mathrm{mM} \mathrm{MgCL} 2,0.2 \mathrm{mM}$ of each dNTP - dATP, dCTP, dGTP, dTTP (100 mM dNTP set, PCR Grade Invitrogen $^{\mathrm{TM}}$ ), $0.4 \mu \mathrm{M}$ primer, and 2.5U Taq DNA polymerase $\left(\right.$ Invitrogen $\left.{ }^{\mathrm{TM}}\right)$. The amplification products were analyzed 
electrophoretically in $1.5 \%$ agarose gel. The gels were photographed utilizing an Image Master-VDS (Pharmacia Biotech) and the images were captured using the computational program LISCAP. The images and the demarcation of the electrophoretic bands were processed by means of the program Sigma Gel (Jandel CO.). The combination of this information generated a matrix of binary data, which was plotted using the system NTSYS version 1.70 (Applied Biostatistcs), applying the program QUALITATIVE and the coefficient of similarity of DICE. Subsequently, these matrices of similarity were transferred to the program SHAN CLUSTERING, where by means of the grouping method UPGMA (unweighted pair-group methods with mathematical average), dendograms were generated, making it possible to determine the degree of similarity and grouping of the possible clonal lines, obtained among the strains of Candida albicans.

\section{RESULTS}

Among 158 strains tested from both groups, caries-active and caries-free, $94 \%$ were positive and $6 \%$ negative for proteinase, while $95.2 \%$ were positive and $4.8 \%$ negative for phospholipase.

The results showed that $89.4 \%$ and $98 \%$ of the total Candida albicans strains of caries-active and caries-free individuals, respectively, were positive for the production of proteinase, whereby only $10.6 \%$ and $2 \%$ of the strains showed negative enzyme activity for the groups, respectively. Student's t-test for two independent specimens revealed a statistically significant difference $(\mathrm{p}=0.0248)$, in relation to the proteinasenegative strains from the two groups studied.

It was shown that $92.3 \%$ of the total strains from the cariesactive individuals and $98 \%$ from caries-free individuals were positive for phospholipase production, whereas $7.7 \%$ and $2 \%$ of the strains demonstrated negative enzyme activity, respectively. Student's t-test revealed a statistically significant difference $(\mathrm{p}=0.034)$ in relation to strains negative for enzyme activity, being more common in the caries-active group (Fig. 2).

The analysis for genetic variability (AP-PCR) existing among the strains of Candida albicans originating from the same individual, revealed that the amplification of genomic DNA of this species, by AP-3 primer, generated AP-PCR products varying between 2.1 and $0.5 \mathrm{bp}$ (Fig. 3).

A greater number of clonal lineages were observed in the group of caries-active versus caries-free volunteers. In the enzyme typing, a higher number of biotypes were found in the caries-active group compared to the caries-free group. However, no statistically significant difference was observed in either case. There was a difference in relation to the number of genotypes and phenotypes in the same volunteer, whereby enzyme production was independent of genotype

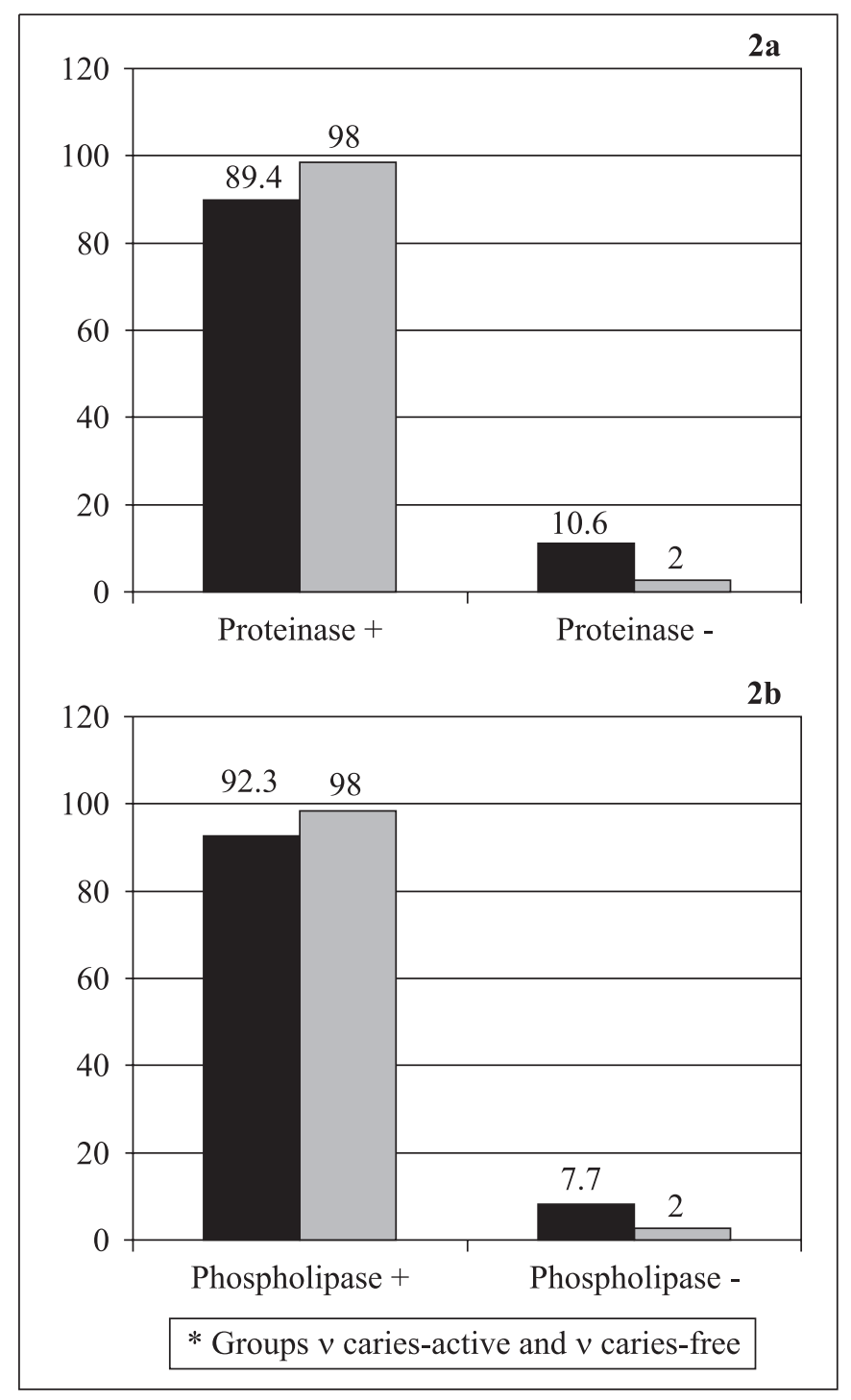

Figure 2. Percentage of Candida albicans strains positive and negative for enzyme activity in the production of proteinase and phospholipase.

Figure 2a: Percentage of strains positive and negative for proteinase activity, in caries-active and caries-free groups.

Figure 2b: Percentage of strains positive and negative for phospholipase activity, in caries-active and caries-free groups.

characteristics, since the same genotype shows different levels of proteinase and phospholipase production.

After AP-PCR determination of profiles of Candida albicans from all the caries-active volunteers, a representative of each clonal lineage was utilized to obtain a representative dendogram. The maximum value of similarity $\left(\mathrm{S}_{\mathrm{SM}}=1.0\right)$ was not found in any clonal type derived from different individuals. The same was observed for the caries-free group. 


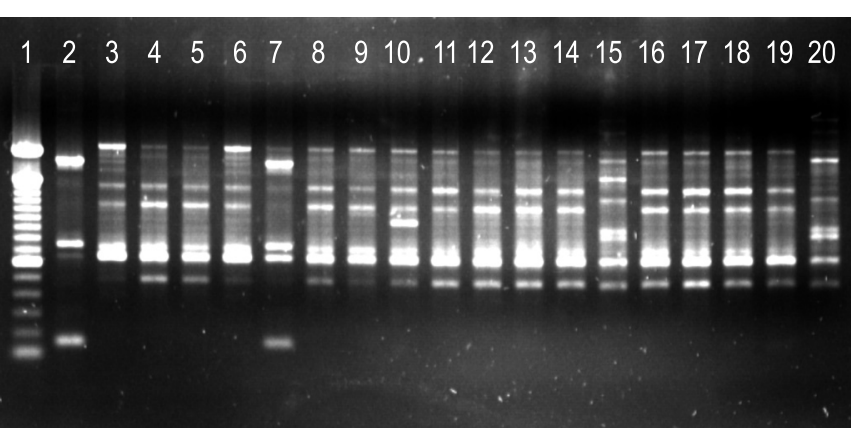

Figure 3. Analysis of genetic variability among Candida albicans strains from the same volunteer.

*1- Molecular weight pattern of $100 \mathrm{bp}$ ladder; 2-20, strains from different sites of the oral cavity. Electrophoretic profiles of Candida albicans isolated from the oral cavity of volunteer 7 , from the caries-active group.

\section{DISCUSSION}

The pathogenicity of the species of Candida spp are a result of the characteristics of the strains, the immunological status of the host and the local conditions of the sites of infection (17).

Candida albicans strains isolated from the oral cavity, demonstrate evident proteinase and phospholipase activity. Some studies of phospholipases such as those by have demonstrated that 30 to $100 \%$ C. albicans strains produce these enzymes $(27,32,37)$. Enzyme activity tests demonstrated that $95.2 \%$ of the C. albicans strains isolated from the oral cavity were positive for phospholipase, which is in accordance with the criteria recommended in studies by Price, et al. (27) and Samaranayake et al (32).

The results obtained in this study demonstrate that, in principle, the phospholipase positive characteristic of $C$. albicans is intrinsic to this species, showing varying degrees of activity. The presence of phosphoipase negative isolates was very small (4.8\%), when compared to the study Price's (27), which demonstrated that $23 \%$ of the oral isolates, $45 \%$ of blood isolates, $50 \%$ of lesion isolates and $70 \%$ of urine isolates were negative.

The results of phospholipase activity demonstrated that 92.3\% of the Candida albicans strains from the caries-active volunteers and $98 \%$ of the strains from the caries-free volunteers were positive for the production of this enzyme, whereas $7.7 \%$ and $2 \%$ respectively, demonstrated negative enzyme activity. These results are partly in agreement with those reported in a phospholipase activity study of oral isolates from patients with and without denture stomatitis (DS) that demonstrated no difference in the production of this enzyme in relation to the clinical aspects observed in the two groups (23). These results are also partly in agreement with results reported by (1), which demonstrated that $83.3 \%$ and $71.9 \%$ of the C. albicans strains produced this enzyme, when isolated from niches with and without lesions characteristic of candidiasis, respectively. However, in comparing virulence factors of $C$. albicans and $C$. dubliniensis, isolated from healthy individuals and patients with chronic candidiasis, showed that $52 \%$ of the C. albicans strains isolated from immuno-compromised patients and $60 \%$ from healthy patients produced phospholipase (7).

The greater number of strains negative for enzyme activity, found in the group of caries-active volunteers, could be related to the type of diet, which was probably richer in sugars. According to Samaranayake et al., 1984 (32), the production of phospholipase by $C$. albicans in vitro decreases with high concentrations of sucrose and galactose, where it is completely inhibited by a high concentration of glucose. In clinical terms, an elevated intra-oral concentration of dietary sugars could suppress the formation of phospholipase, thereby reducing the pathogenic potential of this yeast. While this effect may be beneficial to the host, it could on the other hand lead to increased proliferation of oral yeast (15) and augmented adhesion of yeast to the epithelium (31).

The incidence of proteinase production by $C$. albicans strains can also vary considerably. Of the total strains analyzed in the two groups, $94 \%$ were positive for enzyme production and $6 \%$ demonstrated negative enzyme activity. These data are similar to those obtained by Penha et al., 2000 (25) who studied strains of $C$. albicans from the oral cavity and showed that all of these strains were proteinase producers. Chakrabarti et al. 1991 (2) examined strains of $C$. albicans from different anatomical sites, and found a variation of 44.4 to $84.6 \%$ of strains with positive enzyme activity, depending on the site of origin. Different ecosystems with their specific characteristics, may contain factors in these microenvironments that limit or extend the expression of these enzymes, having as a consequence various degrees of enzyme activity.

The different patterns of proteinase production by strains C. albicans orginating from individuals belonging to the two groups, were greater than those obtained in a study of proteinase in patients with buccal lesions characteristic of candidiasis $(66.7 \%)$ compared to clinically healthy individuals $(68.7 \%)(25)$.

However Wu et al. 1996 (42), reported that C. albicans isolates from patients with HIV infection were significantly more proteolytic than those originating from HIV-negative individuals who have angular chelitis. Of the total strains analyzed, $100 \%$ and $56 \%$ demonstrated positive enzyme activity from patients positive and negative for HIV, respectively. In a study of strains from the oral cavity of HIV-positive and HIV-negative volunteers, showed that all of the isolates were proteolytic, even though secretory activity ( $\mathrm{PZ}$ values) revealed that isolates from HIV-positives were more proteolyic in relation to the control group (23). 
With regard to the expression of virulence factors, not only are microorganism-dependent factors involved, but also others that strongly host-dependent, such as immunological status and local conditions of the site of infection (17). The pathogenicity of $C$. albicans is a complex process, involving different stages, colonization, adherence, invasion of tissues and damage to cells of the host, composition of the cell wall and the production of toxins and proteolytic enzymes $(6,22)$. These factors could influence colonization, survival and the commensal or pathogenic state of these yeast, inducing an increase or diminution of the enzyme levels of these microorganisms.

Using the genotyping technique AP-PCR, the number clonal lines obtained was greater in caries-active than in caries-free volunteers, and in some patients multiple genotypes were detected, although this was not statistically significant.

Hannula et al., 2000 (7) studied clonal differences of $C$. albicans from patients with and without immune compromise, and did not demonstrate significant differences in the distribution of genotypes between ill and healthy individuals, involving only a single genotype of $C$. albicans per individual. Similarly, utilizing the PCR "fingerprinting" technique with 5 different primers, also did not find significant genetic differences in the number of genotypes between HIV-positive and negative groups (44), On the other hand, by karyotyping, found a large clonal diversity of $C$. albicans, among isolates from the oropharanyx of HIV-positive volunteers who had candidiasis (4). Similarly, Howell et al., 1996 (9), in comparing the genetic similarity of $C$. albicans derived from four patients, observed the presence of more than one genotype in some individuals. Meanwhile, studies by Boerlin et al., 1996 (40) of isolates $C$. albicans from the oropharanyx of healthy individuals and patients with HIV typed by MLEE, showed that the majority had a single clone of $C$. albicans in the oropharanyx, with the exception of one patient.

These findings when taken together, demonstrate that it is possible that at least a single genotype can predominate in all the sites of the same individual $(16,39)$. Some patients show stains with reduced genetic diversity $(7,43)$, even though other patients can show alterations in the frequency of phenotypes and genotypes of $C$. albicans $(3,43,44)$, suggesting the existence of a dynamic process of colonization of these species, or the difficulty still in establishing a more defined comparison the phenotypic and genotypic diversity of these microorganisms, using the available methods.

To determine the presence or absence of strains of the same clonal lineage between volunteers of the caries-active and caries-free groups, a representative of each line was selected for the construction of representative dendograms for each group of volunteers. There was not any clonal similarity $\left(\mathrm{S}_{\mathrm{SM}}=1.0\right)$ in different individuals belonging to the same group. Mehta et al., 1999 (19) used DNA "fingerprinting", to analyze systematically 28 healthy individuals belonging to 12 families, with regard to the presence of $C$. albicans from the oral cavity and feces. These investigators demonstrated that different families did not share the same strains, but that two or more members of the same family did. The children studied in the present investigation showed no relation, nor were they from the environment. This may be essential in justifying the differences in findings, in relation to those obtained by Mehta (19). Some authors, nonetheless, have demonstrated that a single cluster, genetically related to Candida albicans infection, usually predominates in a determined population of patients and in a given geographic location $(35,36,37)$.

\section{CONCLUSION}

Although different individuals can share the same or a very similar genotype, the data obtained appear to conform with the majority of studies previously cited, which demonstrated that strains from different locations on the body of the same individual normally possess greater similarity than those derived from different hosts.

These findings demonstrate that the mechanisms involved in the pathogenicity of this species need to be better elucidated. This will likely be possible from diversified research, which permits a greater understanding of the relations of these opportunistic parasites with their host.

It is necessary to consider that the enzyme activity expressed by these microorganisms is only one component of their pathogenic capacity. Other factors already described that determine virulence, should be also included, which makes the phenomenon even more complex. To date, there are still few available data in relation to caries-active and caries-free individuals. The results obtained here open perspectives of new investigations that are aimed at establishing and broadening knowledge of these relations, by studying a greater number of specimens and by employing other molecular techniques, which permit a greater discernment between the genotypic character of this organism and its enzyme profile.

\section{ACKNOWLEDGMENTS}

Sources of support: CAPES; FAEP/Proc. $N^{\circ}$ 0254/02

\section{RESUMO}

\section{Diversidade fenotípica e genotípica entre amostras de Candida albicans isoladas de crianças saudáveis cárie ativas e livre de cárie}

Cepas orais de Candida albicans coletadas de crianças saudáveis cárie ativas e livres de cárie com idade variando de 24 a 36 meses, foram estudadas. O propósito do estudo foi determinar a atividade da proteinase e da fosfolipase produzida 
por Candida albicans nos dois grupos e comparar com a diversidade genotípica usando o método AP-PCR. As cepas identificadas como $C$. albicans por testes morfológicos e de fermentação, foram cultivadas em meio ágar proteinase e fosfolipase a $37^{\circ} \mathrm{C}$ por 7 e 4 dias, respectivamente. Após o período de incubação, a atividade enzimática das cepas proteinase e fosfolipase positiva foram medidas. Todas as cepas foram submetidas a técnica genotípica AP-PCR, usando o primer arbitrário AP-3. A análise enzimática demonstrou que não há diferença entre os dois grupos estudados. O método AP-PCR foi eficiente em demonstrar o polimorfismo genético de $C$. albicans intra indivíduos demonstrando uma maior diversidade clonal em crianças cárie ativas em relação as livres de cárie. Dendogramas de similaridade demonstraram semelhança na linhagem clonal apenas intra-indivíduos. Os resultados sugerem que o perfil enzimático não depende das características genotípicas das cepas.

Palavras chaves: Candida albicans, genotipagem, proteinase, fosfolipase, virulência

\section{REFERENCES}

1. Candido, R.C.; Azevedo, R.V.P.; Komesu, M.C. Enzymotyping of species of the genus Candida isolated from the oral cavity. Rev. Soc. Bras. Med. Trop., 33(5), 437- 442, 2000.

2. Chakrabarti, D.; Nayak, T.; Talwar, P. In vitro proteinase production by Candida species. Mycopathologia, 114(3), 163-168, 1991.

3. Diaz-Guerra, T.M.; Martinez-Suarez, J.V.; Laguna, F.; RodriguezTudela, J.L. Comparison of four molecular typing methods for evaluating genetic diversity among Candida albicans isolates from human immunodeficiency virus-positive patients with oral candidiasis. J. Clin. Microbiol., 35(4), 856-861, 1997.

4. Doyle, J.J.T.; Doyle, J.L. Isolation of plant DNA from fresh tissue. Focus., 12, 13-18, 1990.

5. Gabris, K.; Nagy, G.; Madlena, M.; Denes, Z.; Marton, S.; Keszthelyi, G.; Banoczy, J. Associations between microbiological and salivary caries activity tests and caries experience in Hungarian adolescents. Caries Res., 33(3), 191-195, 1999.

6. Ghannoum, M.A.; Abbu-Elteen, K.H. Pathogenicity determinants of Candida. Mycoses, 33(6), 265-282, 1990.

7. Hannula, J.; Saarela, M.; Dogan, B.; Paatsama, J.; Koukila-Kahkola, P.; Pirinen, S.; Alakomi, H.L.; Perheentupa, J.; Asikainen, S. Comparison of virulence factors of oral Candida dubliniensis and Candida albicans isolates in healthy people and patients with chronic candidosis. Oral Microbiol. Immunol., 15(4), 238-244, 2000.

8. Hellstein, J.; Vawter-Hugart, H.; Fotos, P.; Schmid, J.; Soll, D.R. Genetic similarity and phenotypic diversity of commensal and pathogenic strain of Candida albicans isolated from the oral cavity. J. Clin. Microbiol., 31(12), 3190-3199, 1993.

9. Howell, S.S.; Anthony, R.M.; Power, E. Application of RAPD and restriction enzyme analysis to the study of oral carriage of Candida albicans. Lett. Appl. Microbiol., 22(2), 125-128, 1996.

10. Hube, B. Possible role of proteinases in Candida infections. Rev. Iberoam. Micol., 15, 68-71, 1998.

11. Ibrahim, A.S.; Mirbod, F.; Filler, S.G.; Banno, Y.; Cole, G.T.; Kitajima, Y.; Edwards, J.E. Jr.; Nozawa, Y.; Ghannoum, M.A. Evidence implicating phospholipase as a virulence factor of Candida albicans. Infect. Immun., 63(5), 1993-1998.
12. Jacob, L.S.; Flaitz, C.M.; Nichols, C.M.; Hicks, M.J. Role of dentinal carious lesions in the pathogenesis of oral candidiasis in HIV infections. J. Am. Dent. Assoc., 129(2), 187-194, 1998.

13. Kam, A.P.; Xu, J. Diversity of commensal yeasts within and among healthy hosts. Diagn. Microbiol. Infect. Dis., 43(1), 19-28, 2002.

14. Kleinegger, C.L.; Lockhart, S.R.; Vargas, K.; Soll, D.R. Frequency, intensity, species, and strains of oral Candida vary as a function of host age. J. Clin. Microbiol., 34(9), 2246-2254, 1996.

15. Knight, L.; Fletcher, J. Growth of Candida albicans in saliva: stimulation by glucose associated with antibiotics, corticosteroids, and diabetes mellitus. J. Infect. Dis., 123(4), 371-377, 1971.

16. Lockhart, S.R.; Reed, B.D.; Pierson, C.L.; Soll, D.R. Most frequent scenario for recurrent Candida vaginitis is strain maintenance with "substrain shuffling": demonstration by sequential DNA fingerprinting with probes Ca3, C1 and CARE2. J. Clin. Microbiol., 34(4), 767777, 1996.

17. McCarthy, G.M. Host factors associated with HIV-related oral candidiasis. A review. Oral Surg. Oral Med. Oral Pathol., 73(2), 181-6, 1992.

18. McCullough, M.J.; Clemons, K.V.; Stevens, D.A. Molecular and phenotypic characterization of genotypic Candida albicans subgroups and comparison with Candida dubliniensis and Candida stellaidea. J. Clin. Microbiol., 37(2), 417-421, 1999.

19. Mehta, S.K.; Stevens, D.A.; Mishra, S.K.; Ferone, F.; Pierson, D.L. Distribution of Candida albicans genotypes among family members. Diagn. Microbiol. Infect. Dis., 34(1), 19-25, 1999.

20. Melo, A.S.; de Almeida, L.P.; Colombo, A.L.; Briones, M.R. Evolutionary distances and identification of Candida species in clinical isolates by randomly amplified polymorphic DNA (RAPD). Mycopathologia, 142(2), 57-66, 1998.

21. Negroni, M.; Gonzalez, M.I.; Levin, B.; Cuesta, A.; Iovanniti, C. Candida carriage in the oral mucosa of a student population: adhesiveness of the strains and predisposing factors. Rev. Argent. Microbio., 34(1), 22-8, 2002.

22. Odds, F.C. Recent advances in the biology of Candida. Ann. Biol. Clin., 45(5), 553-557, 1987.

23. Ollert, M.W.; Wende, C.; Gorlich, M.; McMullan-Vogel, C.G.; Borgvon Zepelin, M.; Vogel, C.W.; Korting, H.C. Increased expression of Candida albicans secretory proteinase, a putative virulence factor, in isolates from human immunodeficiency virus-positive patients. J. Clin. Microbiol., 33(10), 2543-2549, 1995.

24. Ollila, P.; Niemela, M.; Uhari, M.; Larmas, M. Risk factors for colonization of salivary lactobacilli and Candida in children. Acta Odontol. Scand., 55(1), 9-13, 1997.

25. Penha, S.S.; Birman, E.G.; Silveira, F.R.X.; Paula, C.R. Frequency and enzymatic activity (proteinase and phospholipase) of Candida albicans from edentulous patients, with and without denture stomatitis. Pesq. Odont. Bras., 14(2), 119-122, 2000.

26. Pfaller, M.A. Epidemiology of nosocomial candidiasis: the importance of molecular typing. Braz. J. Infect. Dis., 4(4), 161167,2000

27. Price, M.F.; Wilkinson, I.D.; Gentry, L.O. Plate method for detection of phospholipase activity in Candida albicans. Sabouraudia, 20(1), 7-14, 1982.

28. Radford, J.R.; Ballantyne, H.M.; Nugent, Z.; Beighton, D.; Robertson, M.; Longbottom, C.; Pitts, N.B. Caries-associated micro-organisms in infants from different socio-economic backgrounds in Scotland. J. Dent., 28(5), 307-312, 2000.

29. Ruchel, R.; Tegeler, R.; Trost, M.A. Comparison of secretory proteinases from different strains of Candida albicans. Sabouraudia, 20(3), 233-244, 1982

30. Saarela, M.; Hannula, J.; Matto, J.; Asikainen, S.; Alaluusua, S. Typing of mutans streptococci by arbitrarily primed polymerase chain reaction. Arch. Oral Biol., 41(8-9), 821-826, 1996. 
31. Samaranayake, L.P.; Macfarlane, T.W. The effect of dietary carbohydrates on the in-vitro adhesion of Candida albicans to epithelial cells. J. Med. Microbiol., 15(4), 511-517, 1982.

32. Samaranayake, L.P.; Raeside, J.M.; MacFarlane, T.W. Factors affecting the phospholipase activity of Candida albicans in vitro. Sabouraudia, 22(3), 201-207, 1984.

33. Sanders, T.A. Diet and general health: dietary counselling. Caries Res., 38(1), 3-8, 2004.

34. Sandven, P. Laboratory identification and sensitivity testing of yeast isolates. Acta Odontol. Scand., 48(1), 27-36, 1990.

35. Schmid, J.; Rotman, M.; Reed, B.; Pierson, C.L.; Soll, D.R. Genetic similarity of Candida albicans strains from vaginitis patients and their sexual partner. J. Clin. Microbiol., 31(1), 39-46, 1993.

36. Schmid, J.; Tay, Y.P.; Wan, L.; Carr, M.; Parr, D.; Mckinney, W. Evidence for nosocomial transmission of Candida albicans obtained by Ca3, / Fingerprinting. J. Clin. Microbiol., 33(5), 1223-1230, 1995.

37. Shimizu, M.T. Enzimas histolisticas produzidas por leveduras do gênero Candida. Rev. Microbiol., 19(4), 442-445, 1988.

38. Stenderup, A. Oral mycology. Acta Odontol. Scand., 48(1), 3-10, 1990.
39. Stevens, D.A.; Odds, F.C.; Scherer, S. Application of DNA typing methods to Candida albicans epidemiology and correlation with phenotype. Rev. Infect. Dis., 12(2), 258-266, 1990.

40. Sullivan, D.; Coleman, D. Candida dubliniensis: characteristics and identification. J. Clin. Microbiol., 36(2), 329-34, 1998.

41. Williams, J.K.G.; Kubelik, A.R.; Livak, K.J.; Rafalski, J.A.; Tingey, S.V. DNA polymorphisms amplified by arbitrary primers are useful as genetic markers. Nucleic Acids Res., 18, 6531-6535, 1990.

42. Wu, T.; Samaranayake, L.P.; Cao, B.Y.; Wang, J. In-vitro proteinase production by oral Candida albicans isolates from individuals with and without HIV infection and its attenuation by antimycotic agents. J. Med. Microbiol., 44(4), 311-316, 1996.

43. Xu, J.; Boyd, C.M.; Livingstone, E.; Meyer, W.; Madden, J.F.; Mitchell, T.G. Species and genotypic diversities and similarities of pathogenic yeasts colonizing women. J. Clin. Microbiol., 37(12), 3835-3843, 1999.

44. Xu, J.; Ramos, A.R.; Vilgalys, R.; Mitchell, T.G. Clonal and Spontaneous Origins of Fluconazole Resistance in Candida albicans. Microbiology, 38(3), 1214-1220, 2000. 